\title{
PARA ONDE VAI A VONTADE GERAL QUANDO A SOCIEDADE DEGENERA?
}

\author{
Márcia Zebina Araújo da Silva \\ Universidade Federal de Goiás (UFG)
}

\begin{abstract}
This paper is a reconstruction and analysis of the establishment of the pact and of the general will in Rousseau's Social Contract, aiming to answer the question posed in the title. The Social Contract is analyzed, especially the concept of general will and the reasons for the institution of the pact, since the political body (the State) is perishable while the general will is indestructible, despite the inevitable degeneration of all things human. We hope to demonstrate, even when considering the paradoxical aspects of the general will, the success of a great idea: the autonomy of the self as free will, being the fundamental idea of modernity.
\end{abstract}

Keywords: general will, contract, nature, freedom, state.

Resumo: Trata-se de uma reconstrução e análise da constituição do pacto e da vontade geral em Do Contrato Social de Rousseau, com o intuito de responder a questão apresentada no título. Analisar-se-á o Contrato Social, especialmente o conceito de vontade geral e as razões para a instituição do pacto, uma vez que o corpo político (o Estado) é perecível enquanto a vontade geral é indestrutível, a despeito da inevitável degeneração das coisas humanas. Buscar-se-á mostrar, mesmo diante dos aspectos paradoxais da vontade geral, o sucesso de uma grande ideia: a autonomia do sujeito como vontade livre, que será a ideia básica da modernidade.

Palavras-chave: vontade geral, contrato, natureza, liberdade, estado.

\section{0 percurso}

A indagação que aparece como o título deste artigo é, na verdade, a questão a que chegamos ao investigar o significado do pacto e da vontade 
geral em Rousseau. Para respondê-la é preciso uma análise acurada do Contrato Social, especialmente do conceito de vontade geral e das razões para a instituição do pacto. A partir da estruturação do corpo moral e coletivo e do conceito que lhe dá a vida - a vontade geral - nos deparamos fatalmente com esta indagação, pois sabemos que, mesmo diante da possibilidade de construção de um mundo moral, este mundo é perecível, já que os homens que dão vida à vontade geral são corruptíveis e o fim do Estado é inevitável. À primeira vista, o fim do corpo político seria também o fim da vontade geral, mas não é o que ocorre. Os homens e os Estados perecem, mas a vontade geral é indestrutível.

Se a vontade geral é imperecível e os Estados estão fadados à degeneração, a indagação sobre o que acontece com a vontade geral tornase inevitável. Com efeito, nossa intenção é tão somente seguir as pistas que esclareçam alguns aspectos fundamentais do conceito de vontade geral para tentar responder a questão inicial acerca do seu destino. Para tal propósito, nos limitaremos ao livro primeiro e aos capítulos iniciais do livro segundo do Contrato Social. Em linhas gerais, nos inspiramos em um excelente artigo de Althusser (1972) ${ }^{1}$, que faz uma leitura do pacto e da vontade geral a partir daquilo que chama de "Desajustes", onde a negação de um desajuste remete a outro, até o ponto final do impasse da teoria com a prática. Embora não seguindo a sua exposição, adotamos alguns aspectos da sua linha de raciocínio. Não obstante, procuraremos ver ao final, nesta indestrutível e certa vontade geral, mais do que apenas um paradoxo último, ou o fracasso de um grande projeto político, como quer Althusser. Ao contrário, por meio desta problemática ideia de uma vontade geral, tal como nos é apresentada por Rousseau, desejamos mostrar o sucesso de uma grande ideia: a autonomia do sujeito como vontade livre, que será a ideia básica da modernidade, como sugere Hegel. Com efeito, neste trabalho, adotamos o seguinte itinerário: (I) apresentação do preâmbulo do Contrato Social, indicando uma a uma as teses recusadas por Rousseau que justificam a origem natural do poder; (II) a constituição do pacto como artifício capaz de manter a liberdade dos homens; (III) a criação desta pessoa moral, a vontade geral, como única força a comandar o Estado preservando a

\footnotetext{
1 ALTHUSSER, L. Sobre el Contrato Social. In: LÉVI-STRAUS, C. et. al., Presencia de Rousseau. Buenos Aires: Ediciones Nueva Visión, 1972, p. 57-101.
} 
liberdade dos seus membros e (IV) a resposta à indagação inicial sobre o destino da vontade geral diante da inevitável degeneração do corpo político.

\section{0 contrato social}

No preâmbulo do Contrato Social Rousseau estabelece seu foco de argumentação e as premissas de onde partirá. Deseja verificar as ordens sociais existentes com o intuito de instituir uma ordem social legítima ancorada nos princípios do direito público, na qual se encontrariam as regras a ser respeitadas na constituição do Estado. A indagação inicial que fundamenta a obra é: "Unir o que o direito permite ao que o interesse prescreve, a fim de que não fiquem separadas a justiça e a utilidade" (CS p.21). ${ }^{2}$ Para tanto, parte de uma dupla série argumentativa em que, de um lado, figuram os homens como são: a partir da busca do que é seguro, do interesse e da utilidade; e, de outro, figuram as leis como podem ser: com base no que é legítimo, direito e justo. Desta forma, investiga a possibilidade de construção da ordem social sem a dissociação do interesse e da legitimidade.

O objeto do primeiro livro do Contrato Social é também o enunciado básico do qual parte e que, ao longo do tratado, irá demonstrar: "O homem nasce livre e por toda a parte encontra-se a ferros" (CS I, I, p. 22), no qual afirma a liberdade como um direito natural fundamental, inalienável e inderivável. Poderíamos atribuir a esta frase inicial o peso de um postulado a partir do qual a ordem social deve ser derivada, pois a liberdade é um predicado que qualifica os homens e os tornam seres verdadeiramente humanos. "Renunciar à liberdade é renunciar à qualidade de homens, aos direitos de humanidade e até aos próprios deveres" (CS I, IV, p. 27). Sem liberdade, portanto, não é possível pensar em ordem social e em legitimidade.

De início, Rousseau recusa a servidão como condição natural, pois ela é contraditória. Afirma de quem exerce o senhorio, a dependência daquele que é escravizado. A ambos falta liberdade: "O que se crê senhor

\footnotetext{
2 ROUSSEAU, J.-J. Do Contrato Social. São Paulo: Abril Cultural, 1978a. (Os Pensadores), p. 21. As demais citações desta obra serão feitas no próprio texto, acompanhadas das iniciais da obra (CS), do número do livro ( I, II, III, ...), do número do capítulo ( I, II, III, ....) e do número da página.
} 
dos demais, não deixa de ser mais escravo do que eles..." (CS I, I, p. 22) ${ }^{3}$, uma vez que o senhor depende do escravo para ser senhor, e vivendo nesta dependência, se crê livre. Sua condição é pior do que a condição do escravo, já que a sua ilusão de liberdade depende do cárcere de outrem. Por seu turno, o escravo se assume como escravo, porque ignora a sua condição naturalmente livre, mas não incorre no duplo engano do senhor que se crê livre e depende dele não se saber como tal. Sem escravos não há escravidão, assim, conclui Rousseau, a dominação é servil porque para existir depende de uma estrutura de falsidade, de um engano. Se existem senhores e escravos isso não decorre de uma diferença de natureza que faria alguns homens nascer para a dominação e outros para a escravidão, como pensava Aristóteles. O que acontece é que os homens nascidos escravos se acostumam com a sua situação, visto que ignoram sua condição naturalmente livres. "Se há, pois, escravo pela natureza é porque houve escravos contra a natureza" (CS I, II, p. 25).

Se o que há são homens não livres tanto na condição de senhor como na condição de escravo; se a liberdade é o elemento fundamental inderivável, postulado para a especificação deste tratado, visto que todos os homens, por serem homens, são livres; estamos diante de um grave problema a ser solucionado: como se estabeleceu a mudança que tirou a humanidade dos homens tornando-os escravos? Um modo de vida em que os homens perdem a qualidade de homens pode ser legitimado? Certamente que não. A passagem da liberdade para a escravidão não é legítima. Porém, Rousseau afirma não conhecer o advento que gerou esta situação desigual. A mudança ocorrida não é o seu objeto neste momento: "No plano do ' $2{ }^{\circ}$ Discurso' trata-se de definir a história provável, as condições da gênese e do desenvolvimento da humanidade, fixando o momento em que se dá a passagem para o estado civil". ${ }^{4}$ Seu objeto neste livro é a constituição do corpo político de forma

\footnotetext{
${ }^{3}$ Com 0 advento da propriedade e da desigualdade os homens acabam por tornarem-se escravos: “... 0 homem, de livre e independente que antes era, devido a uma multidão de novas necessidades passou a estar sujeito, por assim dizer, a toda natureza e, sobretudo, a seus semelhantes dos quais, num certo sentido, se torna escravo, mesmo quando se torna senhor: rico, tem necessidade de seus serviços; pobre, precisa de seu socorro, e a mediocridade não o coloca em situação de viver sem eles". ROUSSEAU, J.-J. Discurso Sobre a Origem e os Fundamentos da Desigualdade entre os Homens, $2^{\circ}$ edição, São Paulo: Abril Cultural, 1978b (Os Pensadores) p. 267. Refiro-me a esta obra no texto como Discurso sobre a desigualdade.

${ }^{4}$ FORTES, L. R. S. Rousseau: o mundo político como vontade e representação. Filosofia Política 2. Porto Alegre: L\&PM Editores, p. 89 - 116, inverno de 1985, p. 92.
} 
legítima e que atenda ao interesse de todos os homens. "No "Contrato", ao contrário, trata-se de estabelecer as condições de legitimidade de toda associação política em geral..." (FORTES, 1985, p. 92).

Entretanto, existem teorias que procuram legitimar a desigualdade. $\mathrm{O}$ próximo passo de Rousseau será, então, desmontar os argumentos que justificam a desigualdade e, a partir do ponto em que ela não pode mais ser justificada logicamente, argumentar em favor da igualdade social em que os homens possam viver associados legitimamente. Se "a ordem social é um direito sagrado que serve de base a todos os outros” (CS I, I, p. 22), então, é pelo direito que a sociedade deverá se manter. Mas temos que investigar sua origem, pois: "Tal direito, no entanto, não se origina da natureza: funda-se em convenções" (Idem), trata-se, então, de saber quais são estas convenções. Num primeiro momento a argumentação é negativa, contra as teorias vigentes; posteriormente torna-se normativa, pois é desta forma que os homens devem agir para criarem uma ordem social legítima que mantenha a liberdade de todos não mais dispersos, mas unidos em torno de um objetivo comum.

A hipótese de um fundamento natural do corpo social baseado na família não pode ser justificada, pois o laço que mantém unidos pais e filhos, no primeiro momento, atende aos ditames da necessidade, estando no âmbito da ordem natural. Mas tão logo os filhos conquistem sua independência, este laço não é mais necessário e se continuam unidos é por vontade própria, ou seja, por convenção.

A hipótese da legitimidade derivada da força não é aceitável (Cf., CS I, III, p. 25). Se fosse legítimo subjugar os outros através da força, seria igualmente legítimo que todos estivessem sempre tentando a usurpação do poder o que geraria não a ordem, mas a desordem social. Os que pretendem ancorar o fundamento da ordem política no poder do mais forte estão invertendo a ordem dos fatos. Se existisse o direito do mais forte e só ele tornasse legítima uma ação, o direito teria como fundamento a violência resultante das disputas em que sempre haveria alguém negando o direito vigente para impor o seu direito com a força. Diante desta instabilidade não haveria direito, já que seria sempre justo depor o mais forte tão logo se obtivesse forças para fazê-lo. Estas ações estariam destituídas de moralidade, visando somente e sempre o interesse imediato. $\mathrm{O}$ direito não poderia jamais ser instituído, pois dependeria do poder que cada homem adquirisse para mudá-lo conforme desejasse. 
Se, por vezes, é preciso ceder à força, não significa que seja uma regra a ser seguida. Tão logo seja possível derrubá-la é legítimo fazê-lo. "Ceder à força constitui ato de necessidade, não de vontade; quando muito, ato de prudência. Em que sentido poderá representar um dever?" (CS I, III, p. 25). Não sendo possível derivar um estatuto moral da força porque ela não faz direito, porque foi o reino da força que obrigou os homens a entrarem em sociedade, Rousseau indaga: “... que direito será esse, que perece quando cessa a força?” (CS I, III, p. 26). Na indagação já está a resposta: o direito que acaba quando cessa a força não é direito, é violência. Quem obedece, o faz por medo e não por respeito. O direito ele mesmo é uma força que as pessoas obedecem por dever e não por necessidade. O objetivo destas indagações, na qual está implícita a preocupação de interação com os demais sujeitos, é responder à questão inicial: qual o fundamento legítimo de uma obrigação moral a ser seguida e qual o direito da autoridade a ser obedecida? O que Rousseau deseja não é uma relação de puro cálculo, pois pretende fazer com que a ordem da legitimidade seja inderivável da ordem do interesse, embora admita que ela deva também ser proveitosa. Portanto, retornamos ao início da argumentação: “... unir o que o direito permite ao que o interesse prescreve...” (CS I, p. 21), observando que a utilidade não é negada, embora não possa ser a fonte da legitimidade.

Com efeito, segundo Rousseau, todo homem tem direito a um convívio ordenado e a ordem social só pode existir e ser preservada se estiver ancorada na legalidade jurídica. Para haver legalidade é preciso a sociedade organizada, e, como tal fato não se origina na natureza são necessárias as convenções para dar vida ao corpo político. É somente pelo artificialismo que o direito se funda e que a sociedade legítima é instituída. A questão de fundo é que os homens "criam" as suas sociedades, legítimas ou não, com base no direito ou na força, mesmo sem terem consciência deste fato. Sendo assim, os homens podem, a partir deste conhecimento, criar uma forma de vida moral que atenda aos interesses e direitos de todos, segundo as regras por eles deliberadas. Se a força não faz direito, e sabemos que é a convenção que torna legítimo o Estado, não é mais possível justificar a desigualdade e a liberdade de uns poucos com base em qualquer outra coisa que não seja a legitimidade convencional. Logo, nenhum homem celebraria acordos para ser dominado, pois estaria infringindo a regra básica de "ser" homem, ou seja, 
preservar a sua liberdade. Diante desta regra, somente a convenção que permita a todos a liberdade e a igualdade possui legitimidade.

\section{Do pacto}

Tendo até aqui recusado uma origem natural do poder, Rousseau deve buscar o fundamento do corpo político em outro paradigma, para isso, precisa verificar qual $\mathrm{o}$ ato que pode fazer da multidão dispersa uma associação. A força não é capaz de tal proeza, pois, se por um lado é capaz de subjugar a multidão e obter a obediência, por outro lado, o jugo poderá ser retirado tão logo se tenha força suficiente para fazê-lo. Isso mostra que existe muita diferença entre uma agregação e uma associação de homens: em ambas há uma multidão, porém, na agregação, os homens se encontram sem uma unidade que lhes dê identidade, sem liberdade e sem direito. Nela não há interesse público, pois o déspota visa somente seus interesses privados e mantém com os membros da agregação a mesma relação do chefe com seus comandados. Ele pode tudo, os membros nada podem. Mantida estas diferenças, é preciso remontar a uma convenção primeira: "Antes, pois, de examinar o ato pelo qual um povo elege um rei, conviria examinar o ato pelo qual um povo é povo" (CS I, V, p. 31), visto que este contrato originário é anterior a todo outro contrato e o verdadeiro fundamento da sociedade.

Rousseau inicia o capítulo VI do Contrato Social com uma conjectura: "Suponhamos os homens chegando àquele ponto em que os obstáculos prejudiciais à sua conservação..." (CS I, VI, p. 31). Como no Discurso sobre a desigualdade, não é necessária a comprovação do fato histórico para justificar a argumentação, já que sua base é hipotética. Se por um lado a argumentação discorre sobre uma passagem que pode ter ocorrido, que os homens possivelmente tenham agido desta forma para criar as sociedades; por outro lado as sociedades existentes não são nenhum exemplo de moralidade, já que foram instituídas mediante um pacto entre ricos e pobres ${ }^{5}$, e não por intermédio do pacto fundamental - o contrato social. Embora sem preocupar-se com verdades históricas, o Discurso sobre

\footnotetext{
${ }^{5}$ Rousseau descreve o pacto que deu origem a sociedade, um pacto orginado pela miséria e guerra constante em que se encontravam os homens. ROUSSEAU, J-J., 1978b, p. 268-269.
} 
a desigualdade é uma narrativa da decadência, que descreve a "história" da sujeição humana, desde a vida natural e feliz dos seus primórdios até a plena submissão e desigualdade. O Contrato Social, pelo contrário, visa restituir a igualdade e a felicidade originária por meio de um contrato que se coloca como o fundamento da legitimidade ${ }^{6}$. O que reforça o aspecto hipotético da formulação e, além disso, salienta seu caráter normativo. Se as sociedades existentes não são morais, certamente é porque nelas ainda impera um chefe e a multidão dispersa. É preciso, pois, que os homens se deem conta da situação e fundem uma sociedade moral, uma vez que voltar à independência natural é impossível, deixar as coisas como estão é impraticável. Chegamos assim à questão fundamental do corpo político que é encontrar uma forma de associação que proteja as pessoas e os bens de cada membro e que os torne tão livres quanto antes, agora, porém, com a liberdade civil.

A solução, de certa forma, já foi anunciada por Rousseau no início de seu tratado, ao salientar que "A ordem social é um direito sagrado... [e que, não obstante], tal direito não se origina na natureza, funda-se, portanto, em convenções" (CS I, I, p. 22). A questão, portanto, é examinar qual é esta convenção.

Vimos que nos capítulos iniciais do Contrato Social a argumentação é negativa, Rousseau critica as interpretações da época que buscavam a fundamentação da sociedade na natureza ou em convenções ilegítimas. Como vimos, ele demonstra que o corpo social não pode fundamentar-se na família e nem no direito do mais forte. Resta então analisar se não seria melhor 'remontar a uma convenção anterior'.

Antes, pois, de examinar o ato pelo qual um povo elege um rei, conviria examinar o ato pelo qual um povo é povo, pois esse ato, sendo necessariamente anterior ao outro, constitui o verdadeiro fundamento da sociedade. (ROUSSEAU, 1978a, I, V, p. 31)

\footnotetext{
${ }^{6}$ Bobbio estabelece esta diferença entre o contrato como fato histórico e o contrato como fundamento de legitimidade, o primeiro foi estabelecido mediante um pacto entre ricos e pobres, o segundo permite ao homem corrompido da sociedade civil 'reencontrar a felicidade, ou ao menos a pureza originária'. Com esta distinção, ele define este segundo pacto, ou o contrato social de Rousseau, como "pura ideia reguladora", numa referência explícita a Kant. Ver BOBBIO, N. e BOVERO, M. Sociedade e Estado na Filosofia Política Moderna. São Paulo: Brasiliense, 1986, p. 64-65.
} 
Este ato através do qual um povo é povo é o ato originário do corpo social e exige, para o seu estabelecimento, a unanimidade. É preciso, então, elucidar como se constitui este corpo e por que.

Suponhamos os homens chegando àquele ponto em que os obstáculos prejudiciais à sua conservação no estado de natureza sobrepujam, pela sua resistência, as forças de que cada indivíduo dispõe para manter-se neste estado. Então, esse estado primitivo já não pode subsistir e o gênero humano, se não mudasse sua maneira de ser, pereceria. (ROUSSEAU, 1978a I, VI, p. 31)

Este ponto a que chegaram os homens, é, no Discurso sobre a desigualdade, o estado de guerra completamente desenvolvido. O gênero humano encontra-se em vias de destruição e a única saída possível é a mudança em sua maneira de viver, mais especialmente, em 'sua maneira de ser'. Este é um momento limite em que os obstáculos à sobrevivência são maiores do que as forças que os homens têm para vencê-los. Estes obstáculos surgem dentro da própria convivência humana, pois neste estágio, estamos diante de homens atomizados vivendo juntos sem constituírem um corpo. Segundo Althusser (1972, p. 63).

Tais obstáculos são puramente internos às relações humanas existentes e levam um nome: são os efeitos de um estado de guerra generalizado, competência universal e, inclusive, no claro de uma paz precária, ameaça constante que cada um sente pesar sobre seus bens, sua liberdade e sua vida.

Como em Hobbes ${ }^{7}$, a situação é de uma guerra latente, pois mesmo em momentos de paz, esta é tão frágil que a ameaça permanece constante.

\footnotetext{
${ }^{7}$ HOBBES, T. Leviatã ou Matéria, Forma e Poder de um Estado Eclesiástico Civil. $3^{\mathrm{a}}$ ed., São Paulo: Abril cultural, 1983, p. 75-73. "[...] durante o tempo em que os homens vivem sem um poder comum de os manter a todos em respeito, eles se encontram naquela condição a que se chama guerra: e uma guerra que é de todos os homens contra todos os homens. Pois a guerra não consiste apenas na batalha, ou no ato de lutar, mas naquele lapso de tempo durante o qual a vontade de travar batalha é suficientemente conhecida", Hobbes pretende mostrar que a natureza da guerra é como a natureza do clima, o mau tempo consiste em uma tendência para chover que dura vários dias, do mesmo modo, a
} 
Em Rousseau, contudo, há um longo desenvolvimento temporal do estado de natureza. $\mathrm{O}$ homem do primeiro estágio do estado natural não tem 'interesse particular', pois vive tão disperso que nada o opõe aos demais uma vez que ainda não estabeleu nenhuma espécie de relação com os outros. A desigualdade advém destes interesses particulares surgidos após um "funesto azar" que introduziu a metalurgia e a agricultura, pois foram "o ferro e o trigo que civilizaram os homens e perderam o gênero humano" (Cf. ROUSSEAU, 1978b, p. 265), dando origem a propriedade. Esta, por sua vez, cria a necessidade da partilha dos bens e o reconhecimento por parte dos demais o que leva os homens a fundarem uma associação de cunho utilitarista que só faz aumentar a desigualdade natural, gerando ricos e pobres, senhores e escravos. Este momento do reino do interesse particular onde a desigualdade impera é um momento aterrador, de perigo constante a todos.

É este o último grau da desigualdade, o ponto extremo que fecha o círculo e toca o ponto de que partimos; então, todos os particulares se tornam iguais, porque nada são, e os súditos não tendo outra lei além da vontade do senhor, nem o senhor outra regra além de suas paixões, as noções do bem e os princípios da justiça desfalecem novamente; então tudo se governa unicamente pela lei do mais forte e, consequentemente, segundo um novo estado de natureza, diverso daquele pelo qual começamos, por ser este um estado de natureza em sua pureza, e o outro, fruto de um excesso de corrupção. (ROUSSEAU, 1978b, p. 280)

Neste estágio vive-se o ápice da desigualdade e, paradoxalmente, todos se tornam iguais - porque são nada e nada podem garantir além da cobiça -; vive-se aqui a radicalidade do interesse particular, que será o móvel da criação da sociedade. "Se a oposição dos interesses particulares tornou necessário o estabelecimento das sociedades, foi o acordo destes mesmos interesses que o possibilitou" (CS II, I, p. 43).

natureza da guerra consiste na disposição para a luta quando não há garantias de paz, e não, necessariamente, em luta real, (cap. XIII). 
A solução dos problemas com os quais os homens se deparam não pode advir de nenhuma exterioridade. A solução não pode vir de Deus, nem do príncipe, nem de qualquer coisa que esteja fora deste quadro limite. Portanto, é dentro desta dispersão corrupta que será buscada a solução que capacite a sobrevivência do homem.

Como os homens não podem engendrar novas forças, mas somente unir e orientar as já existentes, não tem eles outro meio de conservar-se senão formando, por agregação, um conjunto de forças, que possa sobrepujar a resistência, impelindo-os para um só móvel, levando-os a operar em concerto. (ROUSSEAU, 1978a I,VI, p. 31 e 32)

Rousseau, tomando os homens como são, com as forças que cada um dispõe na condição de que nem as forças e nem os obstáculos possam ser alterados, tem como única saída desta situação limite o socorro do artifício e a mudança da maneira de ser dos homens; “[...] e o gênero humano pereceria se a arte não viesse em socorro da natureza". ${ }^{8}$ A mudança ocorre através da agregação destas forças que unidas serão capazes de fazer frente aos mais variados obstáculos. "A única solução possível, interna a este campo teórico constituído pelos homens e as relações alienadas das quais são autores e vítimas, é mudar sua maneira de ser" (ALTHUSSER, 1972, p. 68).

Temos aqui dois aspectos deste mesmo homem. É pela arte, ou seja, pela convenção, que ele continua com a sua vida de homem, porém, no momento que, para continuar vivendo, faz-se necessário o socorro do artifício, alguma coisa muda. Ele é capaz de introduzir a moralidade em suas ações, o que não ocorria no estado de natureza ${ }^{9}$. Portanto, há uma mudança qualitativa e ao mudar sua maneira de ser o homem perde a sua liberdade natural, mas ganha a liberdade moral. Poderíamos dizer que nesse caso ocorre uma troca. $\mathrm{O}$ instante em que a arte intervém já não é mais um

\footnotetext{
${ }^{8}$ ROUSSEAU, J.-J. Du Contrat Social (Première version, Manuscrit de Genève) - Bibliothéque de la Pléiade. Paris: Editions Gallimard, 1964. (I, III, p. 289). Esta obra será referida no texto e nas citações como Manuscrit de Genève.

${ }^{9}$ ROUSSEAU, J-J., 1978b, p.251. "Parece, a princípio, que os homens nesse estado de natureza, não havendo entre si qualquer espécie de relação moral ou de deveres comuns, não poderiam ser nem bons nem maus ou possuir vícios e virtudes...".
} 
instante de mera natureza. Estamos, pois, em vias de tornar legítima esta passagem para outra espécie de vida do homem. Estamos no âmbito da argumentação positiva e normativa. $\mathrm{O}$ enunciado primordial do pacto diz:

Encontrar uma forma de associação que defenda e proteja a pessoa e os bens de cada associado com toda a força comum, e pela qual cada um, unindo-se a todos, só obedece, contudo, a si mesmo, permanecendo assim tão livre quanto antes. (ROUSSEAU, 1978a I, VI, p. 32)

Rousseau tem uma preocupação com a utilidade do pacto: "proteger a pessoa e os bens de cada associado", entretanto amplia o problema introduzindo a questão da legitimidade, que vem a ser o postulado da liberdade a ser garantido pelo direito: “[...] cada um, unindo-se a todos, só obedece a si mesmo, permanecendo assim tão livre quanto antes" (Idem).

Este pacto tem como cláusula a "alienação total e sem reservas" (Cf. CS I, VI, p. 32), pois sendo esta condição igual para todos, ninguém desejará torná-la onerosa aos demais. Este adjetivo que qualifica a alienação de absoluta é, também, a fonte da solução para a manutenção da liberdade, por mais paradoxal que isso possa parecer. Já que cada um dando-se totalmente àquilo que há de comum em todos se dá a si mesmo, o ato de se alienar totalmente torna todos iguais e faz a igualdade da condição com a qual entram em acordo. Assim, só é possível cada um alienar-se a si mesmo, uma vez que cada homem é tomado sob um duplo aspecto, como indivíduo particular e público. Para a instituição do corpo social, esta cláusula faz com que o particular de cada um deixe por instantes de existir para dar vida e existência a essa pessoa moral e coletiva a quem ele se submeterá.

Como os indivíduos antes do pacto não existem enquanto comunidade moral e como, para fazer o pacto, eles têm como cláusula a alienação total à comunidade toda, esta segunda parte do contrato: a comunidade toda, não existe anteriormente ao ato de contratar. "Imediatamente, esse ato de associação produz, em lugar da pessoa particular de cada contratante, um corpo moral e coletivo [...]" (CS I, VI, p. 33). Ou seja, é no ato de contratar

10 Sigo a exposição de Althusser (1972, p. 74-78) para mostrar as peculiaridades do contrato em Rousseau. Althusser chama de Desajuste I o fato de um não-contrato funcionar como contrato, já que não há a segunda parte contratante e nem há intercâmbio entre as partes. 
que surge a segunda parte contratante a quem todo o povo se aliena, porém, esta segunda parte é ela mesma todo o povo neste instante em que "[...] ganha sua unidade, seu eu comum, sua vida e sua vontade" (CS I, VI, p. 33). No instante em que se dão inteiramente não a um terceiro, mas àquilo que é comum a todos, a alienação torna-se tão perfeita que não resta nenhum direito particular a qualquer dos membros capaz de desequilibrar o peso de cada um na associação.

O Contrato de Rousseau, portanto, não pode seguir as normas jurídicas visto que uma das partes contratantes não existe anteriormente ao ato de contratar. No entanto, esta fórmula encontrada para resolver o problema da associação e da constituição do corpo político, que fere as normas dos contratos jurídicos, tem como contrapartida a recusa de toda e qualquer solução transcendente para o problema. Este corpo coletivo que surge mediante o pacto, e que é o soberano, é de fato todo o povo sob a ordem suprema da vontade geral. Este contrato - em que não há sequer a segunda parte contratante enquanto instância independente do ato de contratar - coloca a questão da solução do corpo político na imanência mesma de sua constituição. Com esta especial forma de contrato, Rousseau remete a solução dos problemas humanos - éticos e sociopolíticos - para as mãos humanas, mas para as mãos de todos os homens enquanto iguais e livres, submetidos apenas a eles mesmos enquanto totalidade.

\section{A vontade geral}

Com o contrato firmado "constitui-se um novo espaço, o da cidade, mas também um novo 'tempo', que não é mais o do indivíduo natural, mas o do ser coletivo e artificial constituído pelo grupo" (FORTES, 1985, p. 91). A partir desta decisão que os constitui enquanto grupo associado é por deliberação voluntária que continuam juntos, formando um 'corpo moral e coletivo' que, só por intermédio da união de todos, ganha seu eu comum. Esta 'pessoa moral' não existe independente das pessoas particulares que a constituem, mas ela é mais do que a soma das partes envolvidas, neste sentido, sendo ela constituída pelas vontades particulares naquilo que há de comum entre elas, ela é a vontade soberana: o soberano. Estas mesmas vontades particulares enquanto submetidas às deliberações da vontade soberana são os súditos. É assim que não há e nem pode haver qualquer 
outro poder que obrigue o soberano, pois não há nada de exterior aos próprios particulares que juntos formam o liame social e a vontade geral.

Os indivíduos enquanto vontades particulares podem pensar de forma diferente da vontade do todo, mas devem conformar-se a ela, do contrário devem ser constrangidos a fazê-lo. No momento que firmaram o pacto eles estão presos às regras que o comandam, enquanto particulares. Mas, como cidadãos deliberando pelo bem comum não há nenhuma regra que possa limitá-los.

"Cada indivíduo, com efeito, pode, como homem, ter uma vontade particular, contrária ou diversa da vontade geral que tem como cidadão. Seu interesse particular pode ser muito diferente do interesse comum". (CS I, VII, p. 35) Neste sentido, se os indivíduos enquanto particulares estão submetidos às regras e sujeitos a ser "forçados a ser livre" (CS I, VII, p. 36), o corpo do povo ele mesmo não tem e nem poderia ter qualquer regra que o submetesse, pois ele é o soberano, ou seja, a vontade geral que não tem nenhuma lei fundamental que a obrigue, nem mesmo o Contrato Social.

Como a natureza dá a cada homem um poder absoluto sobre seus membros, o pacto social dá ao corpo político um poder absoluto sobre os seus, e este é o mesmo poder cujo exercício dirigido pela vontade geral tem o nome de soberania. (ROUSSEAU, 1964, I, VI, p.305)

No início do Livro Segundo do Contrato Social reaparece a dupla série argumentativa do interesse e da legitimidade.

[...] só a vontade geral pode dirigir as forças do Estado de acordo com a finalidade de sua instituição, que é o bem comum, porque, se a oposição dos interesses particulares tornou necessário o aparecimento das sociedades, foi $\mathrm{o}$ acordo destes mesmos interesses que o possibilitou. (ROUSSEAU, 1978a, II, I, P. 43)

Os homens se associam por interesse, porém não a qualquer preço, a liberdade deve ser preservada. Se for empenhada perdem os homens a 
"qualidade de homens"11, já que renunciar deliberadamente à liberdade significa renunciar ao que é especificamente humano. Sem liberdade os homens excluem a moralidade de suas ações.

Se a oposição dos interesses tornou necessária a fundação do Estado, para respeitar a cláusula que exige a preservação da liberdade, será necessário fazer da vontade geral a única força a comandá-lo, porque somente deste modo a alienação total de cada associado à comunidade toda fará de cada um, um ser moralmente livre.

Tornar a vontade geral a vontade soberana é fazer com que sejam todos os homens agindo em uníssono a dirigirem o corpo político. O laço comum que une a todos é a convergência dos diferentes interesses, sob a condição da alienação total, que permite manter a todos igualmente livres ${ }^{12}$. Com efeito, sem a convergência das diferentes vontades, tão logo fossem enunciados os juízos particulares seria impossível saber o que é o bem comum, mesmo sabendo que ele é a finalidade do acordo. "O que existe em comum nestes vários interesses forma o liame social”. (CS II, I, p. 43) A noção do bem comum ou do interesse geral surgindo à base do próprio pacto e dos enunciados das vontades particulares não existe anteriormente ao contrato e sem os enunciados dos particulares, ao mesmo tempo em que é o objeto ao qual a vontade geral deve se dirigir para existir. A vontade geral que tem por dever e mesmo como condição de existência dirigir-se somente ao interesse geral, só tem conhecimento do que seja este interesse geral na soma das diferenças dos interesses privados, ou seja, a posteriori; ainda que o interesse particular se oponha, em muitos casos, ao interesse geral: "a vontade particular tende pela sua natureza às predileções e a

\footnotetext{
11 "Renunciar à liberdade é renunciar à qualidade de homem, aos direitos da humanidade e até aos próprios deveres" (CS I, IV, p. 27). Este é um argumento, digamos, 'metafísico', o elemento de exterioridade que garante a inalienabilidade da liberdade e o dever-ser moral que dará legitimidade ao pacto, o fundamento da vontade geral.

${ }^{12} \mathrm{~A}$ formulação de Rousseau antecipa a fórmula kantiana da autonomia da vontade: ser livre é agir por dever, segundo as determinações do imperativo categórico (Kant, I. Crítica da Razão Prática. Lisboa: Edições 70, 1989, p. 12, 45-54); ser livre, para Rousseau, é agir sob a determinação da vontade geral, é renunciar ao arbítrio em nome da liberdade. Fortes $(1985$, p. 93) refere-se à solução teórica encontrada por Rousseau, como uma antecipação da autonomia kantiana. Althusser (1972, p. 86), considera impossível uma leitura kantiana, visto que "o mecanismo da alienação total", impõe a preferência de cada um por si mesmo. Diante do interesse, (a forma do amor de si nas relações sociais) a formulação de Rousseau estaria mais próxima do princípio da reciprocidade: o que quero para mim, quero igualmente para os outros, o que não quero para mim, não quero para os demais.
} 
vontade geral à igualdade" (CS II, I, p. 44). Mesmo assumindo esta oposição entre interesse privado (vontade particular) e interesse público (vontade geral), Rousseau reconhece que a realidade moral necessariamente está fundada em seres factuais e seus interesses privados e embora a criação deste ser moral seja uma ruptura com o ser privado, ela nunca é total. $\mathrm{O}$ interesse público que surge, embora irredutível às partes que o constituem, só pode ser conhecido a partir dos seus enunciados, ou seja, dos diferentes interesses privados $^{13}$. E a garantia de que $\mathrm{o}$ interesse privado não se sobreponha é regrá-lo à base da vontade geral, pois ela constitui a soberania que dá legitimidade às ações que em última instância são os interesses do corpo político.

Ora, como a vontade tende sempre ao bem do ser que quer, que a vontade particular tem sempre por objeto o interesse privado, e a vontade geral o interesse comum, se segue que esta última é ou deve ser só o verdadeiro móvel do corpo social. (ROUSSEAU, 1964, I, IV, p. 295)

Por isso, não é possível delegar poderes a outro que fale em nome da vontade, porque cada um ao se expressar fala do seu próprio interesse através destes atos volitivos e é através da diversidade que surge o interesse geral.

O acordo de todos os interesses se forma por oposição ao de cada um. Se não houvesse interesses diferentes, reconhecerse-ía com dificuldade o interesse comum, que jamais encontraria obstáculos. Tudo andaria por si e a política deixaria de ser uma arte. (ROUSSEAU, 1978a II, III, p.47)

Voltamos assim ao ponto de partida do Contrato Social: o acordo dos diferentes interesses tornou possível o corpo político, e este corpo ganhou forma pela convenção. Se for esta a natureza das coisas, a arte política é aquela que surge da diversidade e que é capaz de lhe dar solução:

\footnotetext{
${ }^{13}$ Algo paradoxal, pois o intreresse privado é apresentado como o fundamento do interesse público e, inclusive, da vontade geral e como o seu contrário. A vontade geral (o oposto da vontade particular) existe porque existe o seu objeto, o interesse geral, mas este, por sua vez, somente existe a partir dos interesses privados.
} 
um eu comum. Solução esta que seja moral e que atenda não somente à ordem do interesse, mas também à ordem da legitimidade.

No capítulo III do Livro Segundo do Contrato Social, contudo, devese observar que Rousseau faz menção à possibilidade de erro da vontade geral, embora afirme que ela é sempre certa e que são as deliberações do povo que podem incorrer em erro. "Deseja-se sempre o próprio bem, mas nem sempre se sabe onde ele está" (II, III, p. 46), o que revela que o povo pode errar por um engano, por um desconhecimento de causa. No entanto, se a predicação do erro é atribuída ao povo, a vontade geral, ela mesma, não erra: "[...] a vontade geral é sempre certa e tende sempre à utilidade pública" (II, III, p. 46). Surge então a pergunta inevitável, o que é esta vontade geral que, por um lado, pode ser aferida como o resultado da soma das diferenças das vontades particulares, sendo um resultado de uma investigação empírica e que, por outro lado, se mantém certa mesmo com o erro daqueles que a constituem, como se fosse uma entidade "metafísica" separada dos sujeitos empíricos?

Vejamos, primeiramente, como Rousseau expõe o problema de aferição da vontade geral: "Quando se retiram, porém, dessas mesmas vontades, os a-mais e os a-menos que nela se destroem mutuamente, resta, como soma das diferenças, a vontade geral" (CS II, III, p. 47). Neste caso, percebe-se que a vontade geral tem um caráter estritamente empírico. Todavia, se este é o mecanismo de declaração da vontade geral, e se há erro nas deliberações do povo que pode se enganar, a consequência é que a vontade geral também se enganaria. Com efeito, Rousseau estabelece as condições para se evitar o erro: que o povo seja educado e informado; que os homens não tenham comunicação entre si ao deliberar - para uma maior diferença entre as vontades - e que não existam sociedades particulares (Cf. CS II, III, p. 47). Contudo, não temos nenhuma garantia que assim se evitará o erro, pois sabemos da inevitável degeneração do corpo político e da indestrutibilidade da vontade geral ${ }^{14}$.

\footnotetext{
14 "Reside aí o vício inerente e inevitável que, desde o nascimento do corpo político tende sem cessar a destruí-lo, assim como a velhice e a morte destroem, por fim, o corpo do homem." (CS III, X, p. 99). Ver também Op. cit. cap. XI, 'Da morte do corpo político', p. 102, e Op. cit. IV, I, p. 117-118.
} 
Na primeira versão do Contrato Social, o Manuscrit de Genève, encontra-se esta sugestiva definição da vontade geral que será suprimida na versão definitiva da obra:

Com efeito, que a vontade geral seja em cada indivíduo um ato puro do entendimento que raciocina no silêncio das paixões sobre isto que o homem pode exigir de seu semelhante, e sobre isto que seu semelhante tem o direito de exigir dele. Ninguém discordará. (ROUSSEAU, 1964, I, II, p.286)

Podemos concluir destas diferentes declarações nas duas versões do Contrato Social que, além de uma dupla determinação de interesse e legitimidade, temos uma dupla determinação do conceito mesmo de vontade geral: um empírico e outro metafísico. Ela decorre dos enunciados dos particulares, sem existir anteriormente às falas e, deste modo, tem um caráter empírico; mas ao mesmo tempo, como "ente de razão" (CS I, VII, p. 35 ), a vontade geral é aquela que existe eternamente e nunca erra, mesmo diante de toda a corrupção dos indivíduos.

Embora cético em relação à eternidade dos governos, Rousseau enumera as precauções que se deve tomar para que se obtenha a vontade geral e que o corpo político tenha uma vida mais longa. É necessário ao corpo político conhecimento do objeto sobre o qual delibera e que este objeto seja geral; que não tenha influências nefastas; que seja esclarecido o suficiente para poder deliberar livremente. É igualmente importante que não existam sociedades ou partidos políticos que falariam em nome dos seus associados, sendo geral em relação a eles, mas particular em relação ao Estado, impedindo um número maior de diferenças entre as vontades, ao ponto de suprimi-las, assumindo então a voz da soberania e acabando com o corpo político. Contudo, mesmo obedecendo a todas estas medidas de precaução, sabemos que havendo erro não foi a voz da vontade geral que falou, mas apenas a voz da vontade privada.

Mantendo a ideia do conhecimento a posteriori da vontade geral, agora tendo como medida de aferição o acerto ou o erro, a boa ou má deliberação do corpo social, concluímos que não há nenhuma garantia de que é a vontade geral quem dirige as forças do Estado. $\mathrm{O}$ acerto ou a boa condução da vida política pode ser um mero acaso. O que ocorre é que, 
diante de uma boa ou má condução do Estado, convencionamos que aquele que funciona bem, funciona segundo as regras desta lei fundamental, a vontade geral. Aquele que não funciona bem e tende a degenerar não segue esta lei fundamental. Assim, o conhecimento da existência da vontade geral conduzindo o Estado é uma simulação de verdade, convencionamos que procuraremos agir moralmente, segundo o bem comum. Se der certo, é porque agimos conforme a vontade geral; se der errado, é porque não ouvimos a sua voz raciocinando no silêncio das paixões, ouvimos apenas as paixões.

Para Rousseau, o tempo em que o laço social se enfraquece é este momento em que as pequenas sociedades começam a influenciar na grande, “[...] então a vontade geral emudece" (CS IV, I, p. 118) porque os homens começam a visar somente seus interesses particulares fazendo-os passar por geral. Neste momento, a força retorna para impor sua voz e ao invés dos indivíduos agirem visando o interesse do Estado, agem somente em nome do interesse privado. "Concluir-se-á daí que a vontade geral esteja aniquilada? Não; ela é sempre constante, inalterável e pura, mas encontra-se subordinada a outras que a sobrepujam" (CS IV, I, p. 118).

Nestas palavras de Rousseau, em que a vontade geral aparece como indestrutível e incorruptível, podemos compreendê-la como uma ideia da razão ${ }^{15}$, como uma entidade abstrata que independe dos enunciados dos homens para existir e que continua viva mesmo com o fim do corpo político. Todavia, vimos que a vontade geral só pode ser aferida a partir da diversidade de interesses dos indivíduos particulares.

Além disso, ao afirmar que quanto mais um Estado aumenta, mais diminui a liberdade das pessoas, Rousseau nos fala sobre a participação de cada um na vontade do todo. Quando maior o número de súditos, menor será a participação de cada um na vontade geral e o Estado tende a degenerar. Nesta equação a vontade geral está intimamente ligada à empiricidade dos fatos sociais e políticos. Nesta acepção pergunto: um ente de razão perde sua racionalidade pelo aumento do número de vontades? Ou

\footnotetext{
15 Podemos também compreender a vontade geral como ideia reguladora, no sentido kantiano do termo, pois a unidade da coletividade que constitui a soberania da vontade geral é abstrata e não encarnada em um homem ou assembleia de homens, como em Hobbes, por isso, também, ela nunca poderá coincidir com a forma real da coletividade, pois esta é empírica, e a vontade geral soberana é abstrata. Fortes (1985, p. 93-94) assinala estes aspectos "kantianos", da vontade geral.
} 
em outros termos, a quantidade altera a qualidade de um ente de razão? Rousseau por um lado responde que não, pois a vontade geral não erra e permanece sempre inalterada. Mas, se é por fatores empíricos que o liame social se desfaz e se a vontade geral só pode surgir através das vontades particulares, então é correto afirmar que a quantidade altera a qualidade e o aumento do número de vontades distancia cada vez mais, cada membro, da vontade geral.

Contudo, como já foi afirmado anteriormente, quanto maior o número das diferenças entre as vontades particulares, maior generalidade tem a vontade geral, visto que o aumento das diferenças quantitativas melhora a qualidade do produto final. Com efeito, estamos diante de um novo paradoxo. $\mathrm{O}$ número maior das diferenças que garante a generalidade acaba por destruir o liame social. Pois bem, Rousseau nos afirma que há problemas porque, para se obter a vontade geral, é preciso os indivíduos isolados, sem interferências de facções diversas e instruídos o suficiente para poder formá-la. Percebe-se, então, que o problema é a realidade dos Estados factuais com seus partidos políticos e interesses mesquinhos e, especialmente, o fato de que quanto maior o Estado, mais problemático e mais difícil de ser governado.

Rousseau (CS II, IX, p. 62-63), com efeito, nos apresenta o tipo de Estado próprio para viver o contrato social. Nem muito rico, que só pense em conquistas e nem muito pobre; nem muito grande pela dificuldade em governar, e nem muito pequeno que não produza o suficiente para a subsistência. Enfim, um Estado ideal que não precise dos outros para se sustentar. Porém, os Estados reais são diversos deste ideal e neles há facções e partidos políticos. Segundo Althusser (1972, p. 93-94), Rousseau acredita na existência do interesse geral como fundamento da sociedade, $o$ que ficou evidente ao nomeá-lo como inalterável, indestrutível, mesmo com o fim do corpo político. Mas no momento em que ele trata das facções e dos interesses de grupos particulares que se fazem passar por geral, se depara na teoria pela primeira vez com a realidade. "[...] Esta vez se trata do Desajuste mesmo da teoria em relação á realidade; pela primeira vez a teoria encontra grupos sociais existentes" (Idem, p. 95). Rousseau rechaça o interesse dos grupos sociais, mas ao negá-los está frente a um dado irredutível da realidade. A solução para as suas dificuldades teóricas estaria em obter na realidade prática a supressão dos partidos, dos grupos políticos; na regressão econômica, mas não há mais retorno possível e estas soluções 
figuram apenas como predições morais. Teríamos então a educação como forma de criar bons cidadãos evitando que acabassem por fazer parte destas facções. A solução estaria, segundo Althusser (1972, p. 101), na "transferência da impossível solução teórica até o outro [lado] da teoria: a literatura". Ou seja, a solução estaria no Emílio, na Nova Heloísa, nas Confissões, visto que dentro do Contrato Social propriamente dito e das relações reais entre os homens não haveria espaço para a soberania da vontade geral e a resolução dos paradoxos apresentados.

\section{Para onde vai a vontade geral quando a sociedade degenera?}

Se a conclusão a que chegamos sobre o contrato social de Rousseau nos remete para a sua pedagogia e literatura, estamos diante de uma grande impotência desta obra, Do Contrato Social, frente à realidade da existência humana e das sociedades políticas criadas por estes. Rousseau (1973, p. 79), quando se declara o homem dos paradoxos, talvez tenha vislumbrado que o paradoxo é próprio das coisas humanas. Se as inúmeras dificuldades que surgem no Contrato Social acabam nos levando para um impasse dentro dele mesmo, estas mesmas dificuldades denotam a preocupação do autor em não fugir a elas, mas enfrentá-las mesmo que remetendo a solução para um passo adiante, até o ponto em que não é possível mais seguir. Se a solução está nas obras de literatura, como sugere Althusser, poderíamos fazer um esforço de não tomá-lo apenas como um sonhador romântico, mas como um filósofo perspicaz que percebeu a fugacidade e a falibilidade das coisas humanas.

A riqueza deste tratado de Rousseau está no fato de não escamotear o profundo problema no âmbito ético-político: encontrar uma solução racional para a atuação da vontade humana finita, permeada por sentimentos e paixões arrebatadoras, sem negá-las, mas procurando adequá-las ao interesse público e à vida em comum. Rousseau procura trabalhar conjuntamente o descritivo com o normativo, o empírico com o puramente racional. Os paradoxos que surgem no tratamento destas questões concernem intrinsecamente ao âmbito próprio da vida política: ao pertencermos a uma sociedade como seres racionais, preocupados com o bem público, somos também seres empíricos, finitos e passionais, assolados por todo tipo de interesses e carências. Como o mundo político é o espaço próprio da existência humana, Rousseau encarou objetivamente o problema, 
buscando manter, com seu estatuto normativo, os aspectos contraditórios da condição de vida dos homens.

A grandeza da obra de Rousseau, que possibilita aproximações tanto com Kant quanto com Hegel, ou, poderíamos falar, da grande fonte que foi Rousseau para estes autores, ancora-se naquilo que a uma leitura superficial nos parece meramente paradoxal e confuso, mas que, se resistirmos a esta primeira impressão, nos remete para o âmago do problema da existência humana e do corpo político. Remete-nos para este obscuro espaço da contradição, da finitude e da imperfeição dos homens que precisam, no entanto, criar um mundo moral, agir como se fossem seres absolutamente racionais, absolutamente sociáveis e livres de qualquer contradição, agindo sempre pelo bem comum.

Se, em última instância, as deliberações da vontade geral não passam de simulação de verdade, talvez seja porque a verdade não pode ser conhecida, afirmação esta que não deixa de ser paradoxal. A natureza própria deste tratado é, portanto, a convenção e o artifício. Chega-se ao ponto em que a verdade buscada que leva à reta conduta social nunca se dá a priori e nem no ato da decisão. Com efeito, a veracidade da conduta a ser seguida é questão que não pode ser decidida. Se a vontade geral é conhecida na enunciação das vontades particulares, não existindo enquanto instância transcendente, a verificação de sua veracidade talvez não seja a questão a ser indagada, uma vez que este método de deliberação busca, antes de tudo, garantir uma forma de decisão legítima para o bom andamento da sociedade. Sendo assim, em sentido estrito, não existe verdade. Em toda deliberação simulamos a veracidade das decisões e é tudo o que pode ser feito. O tempo será o juiz que dirá do acerto (verdade) ou do erro (falsidade) das decisões tomadas. O tempo é que dirá se quem está dirigindo o Estado é a vontade geral ou o interesse privado.

Porém, Rousseau mantém a indestrutibilidade da vontade geral, mesmo diante da inexorável degeneração do Estado. O corpo político, como o corpo do homem é finito e falível, "começa a morrer desde o nascimento e traz em si mesmo as causas de sua destruição" (CS III, XI, p. 102). Há nele um vício inerente e inevitável que desde o seu nascimento tende a destruílo. Mas, é valendo-se desta realidade finita do homem e do corpo político que podemos criar instituições duradouras, pois nos limitaremos a uma realidade possível. Estamos diante de um dever-ser no âmbito estrito da finitude e falibilidade humana, cujo propósito é a criação de um Estado bem 
sucedido, sem a ilusão de torná-lo eterno, pois a eternidade não é própria das coisas humanas.

E nos perguntamos qual será este ponto que resta comum à humanidade, que torna possível o liame social, que permite afirmar da bondade e do amor de si comum a todos os homens, que mesmo sendo sobreposta por outras forças nunca se destrói? Quiçá uma essência da natureza humana que seja boa, como o homem do primeiro estágio do estado natural, livre das ambições e dos vícios notadamente sociais? Rousseau sabe que este estado nunca existiu e, embora permaneça como paradigma do corpo social ao qual sempre nos referimos, não é mais o sonho de liberdade desta vida primitiva que deve ser buscado. O âmbito do Contrato Social é o âmbito da criação de uma segunda natureza humana que, de fato, é a única e verdadeira; aqui o simulacro é a liberdade natural e o homem que a desfruta. A realidade social, porém, é a do estado de guerra, então é preciso um acordo e uma criação de liberdade e igualdade relativas aos limites impostos por esta mesma convenção. O que Rousseau deseja é que os homens tomem o seu destino nas mãos. Que tenham consciência da vida que levam e que saibam que cabe a eles criar uma nova vida caso assim desejarem, uma vez que:

A vida feliz da idade de ouro foi sempre um estado estrangeiro à raça humana, ou por tê-la desconhecido quando teria podido gozá-la, ou por tê-la perdido quando teria podido conhecê-la. (ROUSSEAU, 1964, I, II, p.286)

Esta frase ilustra um aspecto pouco conhecido de Rousseau, mas é emblemática. Ela revela o ceticismo do romântico genebrino e o modo como ele via os homens do hipotético estado natural. Estes homens que supostamente usufruíam de total independência tendo plena satisfação das suas necessidades não poderiam se perceber como livres e felizes. Toda felicidade que desfrutavam, consistia em não conhecer suas próprias misérias. Viviam a imediatez da vida sem pensar sobre si mesmos e sobre a existência. A verdade é que não exerciam a autorreflexão, a capacidade de se ver no mundo, de refletir sobre seus atos e optar por agir bem. Em outras palavras, estes homens não tinham consciência moral, por isso, eram incapazes de imprimir moralidade em suas ações. Exatamente por esta falta de consciência é que acabaram sendo levados pelos acontecimentos de um 
progresso impensado de desigualdades nascentes, até um ponto em que a própria vida da espécie estava ameaçada. Mesmo tendo havido um tempo hipotético em que teria sido possível a autorreflexão antes do Contrato Social, este tempo já não era mais o da vida feliz da idade de ouro da liberdade natural.

Assim, segundo Rousseau, o Contrato Social é a única chance que tem os homens de criar um mundo de liberdade e de igualdade, em que cada um reflita e se compreenda como sujeito livre, com consciência de si mesmo enquanto criador do espaço político, que é o espaço maior onde toda a vida humana se desenvolve. A instituição do Estado conforme o pacto originário é a única possibilidade de criação de um mundo moral que atenda aos requisitos da autonomia da vontade, da preservação da liberdade e que promova o bem comum.

No que se refere ao pacto social, Rousseau consegue evitar qualquer exterioridade às partes contratantes, embora mantendo o postulado da liberdade como o qualificativo do homem. Quando trata da vontade geral e da tendência à degeneração do corpo político guarda um elemento de exterioridade, senão metafísico, ao menos ancorado em suas outras obras. Além da liberdade como postulado, Rousseau precisa algo que garanta a imortalidade da vontade geral mesmo com o fim do Estado.

Numa argumentação interna às partes contratantes, não seria possível termos a vontade geral sem os enunciados dos particulares, logo, a degeneração e corrupção da sociedade seria também o seu fim. Mas sabemos que isso não ocorre. Então, este espaço outro por onde também flutua a vontade geral poderia estar naquilo que há de comum em todos os homens que, inclusive, possibilitou o acordo. Talvez algo como a liberdade fundamental do homem, indestrutível e imutável, como a própria vontade geral que só pode ser eterna à base de alguma exterioridade, ou o desejo comum a todos os homens de buscar a própria felicidade. Em ambos os casos estamos falando do liame social, do que há de comum em todos os homens e os identificam e diferenciam, como uma espécie de universalidade que ultrapassa a existência particular de cada um.

O lugar para onde vai a vontade geral quando a sociedade degenera não tem uma realidade física, mas uma realidade teórico-moral. Se ela passa a existir a partir dos enunciados das diferentes vontades, estes enunciados são expressões do querer e do pensar, naquilo que transcende a própria finitude e falibilidade dos homens. Ao constituir a vontade geral os homens 
ultrapassam a particularidade de cada indivíduo e tornam-se universais. A vontade geral é um elo que eleva a condição humana acima da facticidade do mundo natural do interesse e da necessidade, capaz de fazer "de um animal estúpido e limitado, um ser inteligente e um homem" (CS I, VIII, p. 36). Com a vontade o homem é capaz de pensar em si mesmo, sua condição no mundo e tem a possibilidade de mudá-lo. Pode assumir a criação deste "ser moral" no gozo absoluto da sua liberdade. É à base da vontade geral indestrutível que o homem pode transcender sua condição animal e tornarse racional e autônomo. Podendo fazer isso sempre, mesmo sabendo de sua imperfeição e da degeneração da sua obra. É na vontade do homem enquanto ser racional que repousa a perenidade da vontade geral. Ela surgiu destas vontades e a partir do momento que passou a existir, nada mais pode destruí-la, nem mesmo a vontade dos homens. Os homens podem destruir o corpo político, que é a sua obra, mas a vontade geral, que torna possível esta obra, os transcende. É possível não escutá-la, mas jamais destruí-la.

Se a leitura do Contrato Social, de desajustes em desajustes, nos encaminha para um impasse, já que os problemas não podem ser resolvidos com uma argumentação interna à obra, como sugere Althusser, consideramos que estas críticas, embora procedentes, não servem de índice para assinalar o fracasso de uma teoria. A obra transcende as intenções do autor e a importância ou fracasso que ela adquire na posteridade é algo que lhe foge totalmente. Neste sentido, o sucesso de uma teoria pode ser assinalado pela marca impressa no tempo, nas filosofias que a sucederam. É com este intuito que recorremos à leitura de Hegel da obra de Rousseau, uma vez que compreende a vontade geral como vontade livre e autônoma que ecoa, não apenas no pensamento de Kant, mas, em toda a modernidade filosófica alemã.

Com efeito, Hegel não é um intérprete de Rousseau, mas interessa-se pelo seu pensamento, como de resto, por toda história da filosofia, pois entende que cada filosofia, embora filha do seu tempo, carrega consigo os princípios das filosofias precedentes, revelando um momento fundamental do espírito. ${ }^{16}$ Consequentemente, os sistemas filosóficos não devem ser

\footnotetext{
16 "A filosofia última no tempo é o resultado de todas as filosofias precedentes, e deve, por isso, conter os princípios de todas". HEGEL, G. W. F. Enzyclopädie der philosophischen Wissenschaften. Frankfurt a. M.: Suhrkamp, 1993a, v. 8, § 13, p. 58.
} 
negados, mas compreendidos, porque mostram o aprimoramento do pensamento humano em sua forma mais elaborada e universal. Em sua breve análise de Rousseau, na História da Filosofia, o que importa para Hegel é exatamente o conceito de vontade geral como vontade livre, embora entenda que o alcance especulativo desta formulação não tenha sido abarcado pelo próprio autor. Para Hegel o pensamento puro como princípio e conteúdo foi compreendido como vontade e atividade prática, ainda que seu conteúdo mais íntimo seja o pensamento que se pensa a si mesmo. Todavia, destaca o quão inovadora é a ideia da liberdade da vontade como única fonte de legitimidade do Estado, pois, tomando-se por base esta ideia, não se pode mais justificar o fundamento do Estado em qualquer tipo de violência, como o direito de dominação ou o poder do mais forte. O que a vontade geral encerra, segundo Hegel, é a liberdade das vontades e não o arbítrio dos interesses privados, por isso ela é universal. A vontade geral deve ser compreendida como a vontade racional em si e por si, uma vez que, por seu intermédio "se revela à consciência do homem, como conteúdo, o que o homem tem em seu espírito, a liberdade como o simplesmente absoluto" ${ }^{17}$. A unidade do pensamento consigo mesmo é a liberdade, a vontade livre, que é o conceito mesmo do homem que se concebe como ser pensante.

A vontade é, tão somente, livre-pensamento. O princípio da liberdade nasceu [com Rousseau] e infundiu esta força infinita no homem, que se concebe a si mesmo como infinito. Este princípio é o ponto de transição à filosofia kantiana, a qual, do ponto de vista teórico, toma como base de si este princípio. O conhecimento chegou a sua liberdade, ao seu conteúdo concreto, como conteúdo que tinha em sua consciência. (HEGEL, 1993b, p. 308)

A ideia da vontade livre veio à tona com o pensamento de Rousseau e, a partir de então, não há mais retorno, é a própria consciência do pensamento que procura na realidade uma forma de torná-la racional, ou seja, moral. Pois o conceito de vontade livre é o conceito de ser pensante

17 HEGEL, G.W.F. Vorlesungen über die Geschichte der Philosophie III. Frankfurt a. M.: Suhrkamp, 1993b, v. 20, p. 307-308. 
que se autodetermina e, deste modo, livre, tem a possibilidade de criar um mundo moral, visto que "a pessoa moral que constitui o Estado [deve ser considerada] como um ente de razão, porquanto não é um homem" (CS I, VII, p. 35). Após ter atingido este estágio da autonomia do eu não é possível mais recuar e, talvez, o conceito de vontade geral como indestrutível repouse nesta impossibilidade. ${ }^{18}$

Assim, tendo saído de Rousseau e buscado o entendimento desta perene vontade geral na explicação de Hegel, ela é possível dentro do Contrato Social e é, na verdade, a única saída para a compreensão deste ente de razão, constituído pelas livres vontades, que é transcendente e imanente ao mesmo tempo. Deste modo, poderemos ler o texto de Rousseau sem pensarmos no fracasso desta admirável teoria sem precedentes que é o Contrato Social, como nos diz Althusser, mas pensarmos no sucesso desta ideia sem precedentes que é a vontade geral, como princípio da liberdade e da autonomia do sujeito, com uma força tal que permite ao homem se conceber como infinito, como nos diz Hegel.

\footnotetext{
${ }_{18}$ Gostaríamos de assinalar que o conceito de vontade geral também tem semelhanças com a ideia de "espírito do mundo" em Hegel, que é, igualmente, indestrutível e, diante da decadência de um povo, migra para outro, sem voltar jamais ao mesmo lugar. Em Rousseau também encontramos esta impossibilidade, e um povo que já tenha vivido livre sob a égide de vontade geral, depois que definha, não retoma mais a sua liberdade.
} 


\section{Referências:}

ABRAMSON, J. Rousseau and the Political. In: Minerva's owl : the tradition of western political thought, Cambridge, Massachusetts., London: Harvard University Press, 2009, p. 243-257.

ALTHUSSER, L. Sobre el Contrato Social. In: LÉVI-STRAUS, C. et. al., Presencia de Rousseau. Buenos Aires: Ediciones Nueva Visión, p. 57-101, 1972.

BOBBIO, N. e BOVERO, M. Sociedade e Estado na Filosofia Política Moderna. São Paulo: Brasiliense, 1986.

CASSIRER, E. A questão Jean-Jacques Rousseau. São Paulo: Editora UNESP, 1999.

DENT, N. J. H. Dicionário Rousseau. Rio de Janeiro: Jorge Zahar Ed., 1996.

DERATHÉ, R. J.-J. Rousseau et la science politique de son temps, Paris: Vrin, 1995.

FORTES, L. R. S. Rousseau: o mundo político como vontade e representação. In: Filosofia Política 2. Porto Alegre: L\&PM Editores, p. 89 - 116, inverno de 1985. . Rousseau: da teoria à prática. São Paulo: Ática, 1976.

HEGEL, G.W.F. Enzyclopädie der philosophischen Wissenschaften. Frankfurt a. M.: Suhrkamp, 1993a, v. 8. . Vorlesungen über die Geschichte der Philosophie III. Frankfurt a. M.:

Suhrkamp, 1993b, v. 20.

HOBBES, T. Leviatã ou Matéria, Forma e Poder de um Estado Eclesiástico Civil. $3^{\text {a }}$ ed., São Paulo: Abril cultural, 1983.

KANT, I. Crítica da Razão Prática. Lisboa: Edições 70, 1989.

RILEY, P. Rousseau's general will. In: The Cambridge Companion to Rousseau. Cambridge: Cambridge University Press, 2001, p. 124-153.

ROUSSEAU, J.-J. Do Contrato Social. $2^{\mathrm{a}}$ ed., São Paulo: Abril Cultural, 1978a. . Discurso Sobre a Origem e os Fundamentos da Desigualdade entre os Homens, $2^{\circ}$ edição, São Paulo: Abril Cultural, 1978b.

. Emílio ou da educação. 2a . ed., São Paulo: Difusão Européia do Livro, 1973.

. Du Contrat Social ( Première version, Manuscrit de Genève ) - Paris:

Editions Gallimard, Bibliothéque de la Pléiade, 1964. 
QVORTRUP, M. The political philosophy of Jean-Jacques Rousseau, the impossibility of reason. Manchester: Manchester University Press, 2003.

Email:marciazebina@gmail.com

Recebido em: Abril de 2011

Aprovado em: Maio de 2011 